\title{
Alternative Pathways for the Biosynthesis of Alginate from Fructose and Glucose in Pseudomonas mendocina and Azotobacter vinelandii
}

\author{
By A. J. ANDERSON, ${ }^{*}$ A. J. HACKING ${ }^{2}$ AND E. A. DAWES ${ }^{1}$ \\ ${ }^{1}$ Department of Biochemistry, University of Hull, Hull HU6 $7 R X, U K$ \\ ${ }^{2}$ Tate and Lyle Group Research and Development, Philip Lyle Memorial Research Laboratory, \\ PO Box 68, Reading RG6 $2 B X, U K$
}

(Received 20 October 1986; revised 19 December 1986)

\begin{abstract}
The incorporation of specifically labelled sugars into alginate by mucoid strains of both Pseudomonas mendocina and Azotobacter vinelandii resulted in substantially different labelling patterns for fructose and glucose. Alginate was synthesized principally from degradation products of glucose, whereas the majority of the polymer produced from fructose was assembled from intact hexose units. A possible explanation for the limited synthesis of alginate from undegraded glucose molecules is that one of the necessary enzymes, glucose-phosphate isomerase, is subject to inhibition by 6-phosphogluconate, a metabolite involved in the catabolism of sugars via the Entner-Doudoroff pathway in both of the organisms.
\end{abstract}

\section{INTRODUCTION}

The pathway of alginic acid biosynthesis in the brown alga Fucus gardneri has been described by Lin \& Hassid (1966). Early studies suggested that the biosynthesis of bacterial alginate occurred via a similar pathway, since the necessary enzymes were detected in alginateproducing strains of both Azotobacter vinelandii (Pindar \& Bucke, 1975) and Pseudomonas aeruginosa (Piggott et al., 1981). More recently, Banerjee et al. (1983) failed to detect phosphomannose isomerase (PMI) and phosphomannomutase, both enzymes of the putative biosynthetic pathway, in alginate-producing strains of $P$. aeruginosa. With the aid of mutants possessing known enzymic deficiencies, these authors demonstrated the involvement of enzymes of the Entner-Doudoroff pathway in the synthesis of alginate from glucose or gluconate by this organism and it was proposed that glyceraldehyde 3-phosphate was a precursor in the biosynthesis of the polymer.

Studies on the incorporation of isotope from specifically labelled glucose (Lynn \& Sokatch, 1984) showed that, although there was extensive incorporation of C-6 from glucose into alginate in both $A$. vinelandii and $P$. aeruginosa, only a small proportion of $\mathrm{C}-1$ and $\mathrm{C}-2$ was incorporated into polymer. It was suggested that the synthesis of uronic acid monomers occurred preferentially from C-4, C-5 and C-6 of glucose by the condensation of triose phosphates.

Although PMI was not detected in alginate-producing strains of $P$. aeruginosa, incorporation of a cloned gene specifying PMI activity restored alginate synthesis in an alginate-negative mutant (Darzins et al., 1985); this implies that PMI is essential for alginate synthesis from glucose, despite the fact that the enzyme could not be detected by the normal assay method. Recently, Gill et al. (1986) reported that PMI activity could be detected when the gene was overexpressed. A non-mucoid variant of $A$. vinelandii was found (Horan et al., 1983) to lack the key enzymes of alginate biosynthesis, and non-mucoid variants of $P$. aeruginosa have been reported (Pugashetti et al., 1983) to lack GDP-mannose dehydrogenase.

Abbreviations: FBP, fructose 1,6-bisphosphate; F6P, fructose 6-phosphate; GDH, glycerol-3-phosphate dehydrogenase; G6PD, glucose-6-phosphate dehydrogenase; 6PG, 6-phosphogluconate; PGI, glucose-6phosphate isomerase: PMI, phosphomannose isomerase: TPI, triose-phosphate isomerase. 
Fructose-1,6-bisphosphate aldolase has been shown to be an essential enzyme in alginate biosynthesis from glucose or gluconate by $P$. aeruginosa (Banerjee et al., 1985). Thus, the principal pathway of alginate formation from these carbon sources appears to involve degradation via the Entner-Doudoroff pathway, followed by synthesis of fructose 1,6bisphosphate (FBP) from two molecules of glyceraldehyde 3-phosphate by the (reverse) aldolase reaction; subsequent dephosphorylation to fructose 6-phosphate (F6P) would enable polymer synthesis to continue via the reactions that were originally proposed for the synthesis of bacterial alginate.

Whilst the Entner-Doudoroff pathway is clearly involved in synthesis of alginate from glucose, it is apparent from the data of Banerjee et al. $(1983,1985)$ that washed cell suspensions of mutant strains of $P$. aeruginosa having lesions in glucose-6-phosphate dehydrogenase (G6PD), 2-keto-3-deoxy-6-phosphogluconate aldolase, glucose-6-phosphate isomerase (PGI) or fructose-1,6-bisphosphatase retain the ability to produce alginate from fructose. This finding indicates that the polymer must be synthesized from fructose via an alternative pathway.

We have compared the incorporation of isotope into alginate from specifically labelled fructose and glucose by efficient alginate-producing strains of $P$. mendocina and $A$. vinelandii and suggest an explanation for the differences observed.

\section{METHODS}

Growth of $P$. mendocina in continuous culture. $P$. mendocina NCIB 11687 was grown under nitrogen limitation in a chemostat at a low dissolved oxygen tension $(40 \pm 5 \mathrm{mmHg})$; the $\mathrm{pH}$ was controlled at $7.0 \pm 0 \cdot 1$ and the dilution rate was $0.05 \mathrm{~h}^{-1}$. The medium contained $\left(\mathrm{gl}^{-1}\right)$ : glucose, $50 ;\left(\mathrm{NH}_{4}\right)_{2} \mathrm{HPO}_{4}, 1 \cdot 25 ; \mathrm{K}_{2} \mathrm{HPO}_{4}, 1 \cdot 25 ; \mathrm{CaCl}_{2} .2 \mathrm{H}_{2} \mathrm{O}$, $0 \cdot 1 ; \mathrm{MgSO}_{4} .7 \mathrm{H}_{2} \mathrm{O}, 0.4$; citric acid, 0.99 ; yeast extract (Oxoid), $0.2 ; \mathrm{MnSO}_{4} \cdot 4 \mathrm{H}_{2} \mathrm{O}, 1 \cdot 1 \times 10^{-3} ; \mathrm{ZnSO}_{4} .7 \mathrm{H}_{2} \mathrm{O}$, $2 \times 10^{-4} ; \mathrm{CoSO}_{4} .7 \mathrm{H}_{2} \mathrm{O}, 2.8 \times 10^{-4} ; \mathrm{CuSO}_{4} .5 \mathrm{H}_{2} \mathrm{O}, 2.5 \times 10^{-4} ; \mathrm{H}_{3} \mathrm{BO}_{3}, 6 \times 10^{-5} ;$ and $\mathrm{FeSO}_{4} .7 \mathrm{H}_{2} \mathrm{O}$, $3.6 \times 10^{-3}$. The glucose was autoclaved separately.

Growth of bacteria in batch culture. A. vinelandii SM 52B (Tate and Lyle Ltd) was grown in the medium of Horan et al. (1983), except that either fructose or glucose replaced sucrose as the carbon source. P. mendocina NCIB 11687 was grown in medium similar to that described by Jayasuria (1955), but with an elevated phosphate concentration (100 mM-total phosphate) to improve the buffering capacity and either fructose or glucose as carbon source. The growth media were autoclaved without the sugars, which were separately sterilized by membrane filtration. For isotopic experiments, flasks ( 1 l) containing medium $(250 \mathrm{ml})$ were used; the radioisotope [approximately $2 \mu \mathrm{Ci}$ $(74 \mathrm{kBq})]$ was filter-sterilized with the carbon source. Samples of growth media were retained to determine the exact specific activity of the carbon source present in each flask. Bacteria were subcultured twice in the appropriate medium prior to inoculation $(1 \%, v / v)$ and the flasks were incubated at $30^{\circ} \mathrm{C}$, with shaking, until the carbon source was exhausted. In the case of fructose cultures of $P$. mendocina, growth was very slow and it was necessary to add a protease to the growth medium to decrease degradation of the alginate by alginate lyase; Neutrase (Novo; $1 \mathrm{AU}^{-1}$ ) was included in the growth medium.

Preparation of specifically labelled fructose. $\left[1-{ }^{14} \mathrm{C}\right]$ Fructose and $\left[6^{-14} \mathrm{C}\right]$ fructose were prepared from specifically labelled glucose with the aid of immobilized glucose isomerase. Glucose $(0.5 \mathrm{~g})$ and specifically labelled glucose $\left[20 \mu \mathrm{Ci}, 55 \mathrm{Ci} \mathrm{mol}^{-1}\left(340 \mathrm{kBq}, 2.03 \mathrm{TBq} \mathrm{mol}^{-1}\right)\right]$ were incubated with Sweetzyme Q (Novo; $0 \cdot 1 \mathrm{~g}$ ) in a total volume of $1 \mathrm{ml}$. The reaction was allowed to proceed until equilibrium was attained $(50 \mathrm{~h})$, at which time fructose and glucose were present in approximately equal concentrations. The sugar solution was removed and heated at $100^{\circ} \mathrm{C}$ for $10 \mathrm{~min}$ to inactivate any solubilized enzyme.

To facilitate the separation of fructose from the mixture of sugars, the glucose was selectively phosphorylated. The mixture was incubated at $37^{\circ} \mathrm{C}$ in $50 \mathrm{~mm}$-sodium phosphate buffer $(50 \mathrm{ml}, \mathrm{pH} 7 \cdot 0)$ containing glucokinase (2.5 U), $\mathrm{MgCl}_{2}(5 \mathrm{mM})$ and ATP $(1 \mathrm{~g})$ until no free glucose remained. The solution was passed through a column of Dowex $1 \times 2$ (carbonate form) resin, followed by Dowex $50 \mathrm{~W} \times 8$ (ammonium form) resin to remove glucose 6phosphate and buffer. Ammonium carbonate was removed by repeated rotary evaporation at $30^{\circ} \mathrm{C}$. The specifically labelled fructose was shown to be free of phosphates and the extent of contamination by glucose, resulting from the non-enzymic interconversion of the sugars in alkaline solution, was less than $2 \%(w / w)$.

Analytical methods. Glucose was estimated by the glucose oxidase method, using a commercial kit (Boehringer). Fructose was determined by the resorcinol method (Herbert et al., 1971). The method of Kalb \& Bernlohr (1977) was used to determine the concentration of protein in cell-free extracts. Alginate was determined both by uronic acid analysis (Blumenkrantz \& Absoe-Hansen, 1973), using commercial alginic acid (Sigma, type III) as standard, and gravimetrically by drying samples to constant weight at $110^{\circ} \mathrm{C}$. The radioactivity of aqueous solutions was measured by liquid scintillation counting in the scintillant of Bray (1960).

Isolation and purification of alginate. Radiolabelled cultures were centrifuged $\left(4{ }^{\circ} \mathrm{C}\right)$ at $40000 \mathrm{~g}$ for $30 \mathrm{~min}$ to sediment the bacteria and the supernatant solution was centrifuged again, under the same conditions, to ensure 
that no bacteria remained in the crude alginate solution. In the case of $A$. vinelandii cultures, $\mathrm{NaCl}(100 \mathrm{mM})$ and EDTA (disodium salt, $10 \mathrm{mM}$ ) were incorporated, prior to centrifugation, to facilitate clarification of the alginate solution, as described by Horan et al. (1983).

Alginate was precipitated from the supernatant solution $(200 \mathrm{ml})$ by shaking with 3 vols propan-2-ol; the gel so obtained was dissolved in the minimum volume of water $(100-300 \mathrm{ml})$ by vigorous stirring and reprecipitated twice from solution. The alginate solution was subjected to exhaustive dialysis $\left(4^{\circ} \mathrm{C}\right)$ against water to remove traces of propan-2-ol and low- $M_{\mathrm{r}}$ material. The specific activity of the resulting viscous alginate solution was determined.

To measure the yield of alginate produced by $A$. vinelandii, cultures were harvested after exhaustion of the carbon source and the polymer was recovered from measured volumes of supernatant fluid by a single precipitation with propan-2-ol; it was established that no more alginate could be precipitated by increasing the concentration of propan-2-ol.

Enzyme assays. All assays were carried out at $30^{\circ} \mathrm{C}$. Cell-free extracts were prepared essentially as described by Mitchell \& Dawes (1982).

Fructokinase (EC 2.7.1.4) and 1-phosphofructokinase (EC 2.7.1.56) were assayed by the methods of van Dijken \& Quayle (1977).

Glucose-6-phosphate dehydrogenase (EC 1.1.1.49) was assayed as described by Anderson \& Dawes (1985), except that the $\mathrm{pH}$ of the buffer was $8 \cdot 3$.

Glucose-6-phosphate isomerase (EC 5.3.1.9) was assayed in a mixture ( $1 \mathrm{ml}$ ) containing Tris/ $\mathrm{HCl}$ buffer $(\mathrm{pH} 8 \cdot 2$ at $\left.30{ }^{\circ} \mathrm{C}, 50 \mu \mathrm{mol}\right)$, DTT $(5 \mu \mathrm{mol})$, NADP $(1 \mu \mathrm{mol})$, F6P $(4 \mu \mathrm{mol})$ and G6PD $(5 \mathrm{U})$. The reaction was initiated by addition of the cell extract after contaminating glucose 6-phosphate, present in the F6P, had been consumed. For inhibition studies with 6-phosphogluconate (6PG), NaF (50 mM) was included in the assay to inhibit 6phosphogluconate dehydratase (Kovachevich \& Wood, 1955).

Fructose-1,6-bisphosphate aldolase (EC 4.1.2.13) was assayed in a mixture ( $1 \mathrm{ml})$ containing sodium borate buffer (pH 9.3, $50 \mu \mathrm{mol})$, DTT $(1 \mu \mathrm{mol}), \mathrm{MgSO}_{4}(6 \cdot 3 \mu \mathrm{mol})$, FBP $(1 \mu \mathrm{mol}), \mathrm{NADH}(0 \cdot 15 \mu \mathrm{mol}), \mathrm{KCl}(63 \mu \mathrm{mol})$, triose-phosphate isomerase [TPI (EC 5.3.1.1): $26 \mathrm{U}$ ] and glycerol-3-phosphate dehydrogenase [GDH (EC 1.1.99.5): $4 \mathrm{U}]$.

Fructose-1,6-bisphosphatase (EC 3.1.3.11) was assayed in a mixture (1 ml) containing sodium borate buffer (pH 9.5, $50 \mu \mathrm{mol}), \mathrm{MgCl}_{2}(20 \mu \mathrm{mol})$, NADP $(3 \mu \mathrm{mol})$, FBP $(2 \mu \mathrm{mol})$, PGI (5 U) and G6PD (2 U).

Phosphofructokinase (EC 2.7.1.11) was assayed in a mixture $(1 \mathrm{ml})$ containing Tris/ $\mathrm{HCl}$ buffer $\left(\mathrm{pH} 8.0\right.$ at $30^{\circ} \mathrm{C}$, $40 \mu \mathrm{mol}), \mathrm{DTT}(1 \mu \mathrm{mol}), \mathrm{MgSO}_{4}(6.3 \mu \mathrm{mol}), \mathrm{KCl}(63 \mu \mathrm{mol}), \operatorname{ATP}(3.6 \mu \mathrm{mol}), \mathrm{NADH}(0.3 \mu \mathrm{mol}), \mathrm{TPI}(11 \mathrm{U})$ and GDH (2 U).

Other enzyme assays were carried out by the procedures described, or referred to, by Mitchell \& Dawes (1982). Specific activities are expressed as $\mathrm{nmol} \mathrm{min}^{-1}(\mathrm{mg} \text { protein })^{-1}$.

Materials. Specifically labelled glucose $\left[50-60 \mathrm{mCi} \mathrm{mmol}^{-1}\left(1 \cdot 85-2 \cdot 22 \mathrm{GBq} \mathrm{mmol}^{-1}\right)\right]$ was obtained from Amersham.

Glucokinase was purified by affinity chromatography (Doelle, 1982) from Zymomonas mobilis CP4. The organism was grown and cell-free extracts were prepared as described by Anderson \& Dawes (1985). The purified enzyme possessed no fructokinase activity.

Other enzymes and biochemicals were purchased from Sigma.

\section{RESULTS AND DISCUSSION}

\section{Incorporation of specifically labelled sugars into alginate}

The organisms chosen for this study are mutants of $A$. vinelandii and $P$. mendocina that have previously been selected for their ability to produce enhanced concentrations of alginic acid (Horan et al., 1983; Hacking et al., 1983). Fructose supported growth and alginate production in both organisms, although the rate of uptake was lower than that of glucose (Fig. 1), especially in the case of $P$. mendocina. The related organism, P. aeruginosa, has also been reported to exhibit a low growth rate with fructose as the sole carbon source (Sawyer et al., 1977).

The initial concentration of fructose and glucose for the radioactive-labelling experiments was chosen, in each case, as the highest concentration that was completely utilized in batch culture, without being preceded by a period of very slow uptake. The utilization of fructose and glucose by both organisms is shown in Fig. 1 . In the case of $P$. mendocina, fructose utilization was slow and incomplete, even at low substrate concentration $\left(10 \mathrm{~g} \mathrm{l}^{-1}\right)$, and recovery of alginate from the culture by precipitation was very poor because the polymer was extensively degraded by alginate lyase during the extended incubation period. The inclusion of a proteolytic enzyme 


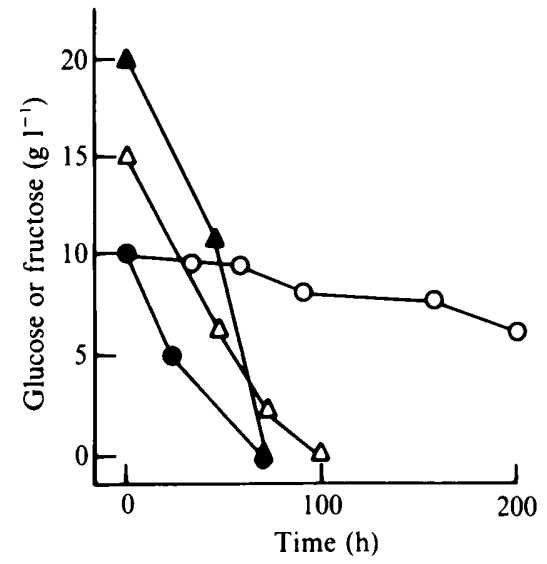

Fig. 1

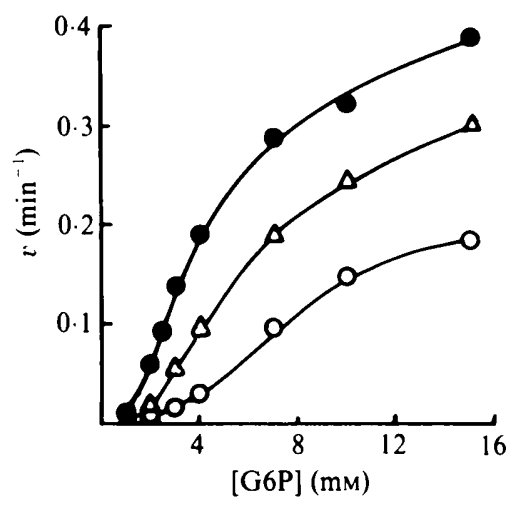

Fig. 2

Fig. 1. Utilization of fructose (open symbols) and glucose (filled symbols) by $A$. vinelandii $(\triangle, \Delta)$ and $P$. mendocina $(\mathrm{O}, \mathrm{O})$ growing in shake-flask cultures at $30^{\circ} \mathrm{C}$.

Fig. 2. Inhibition of G6PD from $P$. mendocina by ATP, with NAD (1 mM) as cofactor. A constant amount of enzyme ( $0.15 \mathrm{mg}$ protein) was present in each assay. ATP concentrations (mM): 0,$0 ; \triangle, 1$; $0,2 \cdot 5$.

Table 1. Incorporation of specifically labelled glucose and fructose into alginate

$\begin{array}{clccc}\text { Organism } & \text { Substrate } & \begin{array}{c}\text { Relative specific } \\ \text { activity of alginate* }\end{array} & \begin{array}{c}\text { Standard } \\ \text { deviation }\end{array} & \begin{array}{c}\text { No. of } \\ \text { expts }\end{array} \\ \text { A. vinelandii } & {\left[1^{14} \mathrm{C}\right] \text { Glucose }} & 0.13 & 0.03 & 2 \\ & {\left[2^{14} \mathrm{C}\right] \text { Glucose }} & 0.30 & 0.01 & 2 \\ \text { P. mendocina } & {\left[6^{14} \mathrm{C}\right] \text { Glucose }} & 1.76 & 0.10 & 2 \\ & {\left[1^{14} \mathrm{C}\right] \text { Glucose }} & 0.08 & 0.01 & 3 \\ & {\left[2^{14} \mathrm{C}\right] \text { Glucose }} & 0.35 & 0 & 2 \\ \text { A. vinelandii } & {\left[6^{14} \mathrm{C}\right] \text { Glucose }} & 1.54 & 0.02 & 3 \\ & {\left[1^{14} \mathrm{C}\right] \text { Fructose }} & 0.78 & 0.10 & 4 \\ \text { P. mendocina } & {\left[6^{14} \mathrm{C}\right] \text { Fructose }} & 1.08 & 0.03 & 3 \\ & {\left[1^{14} \mathrm{C}\right] \text { Fructose }} & 0.91 & 0.13 & 3 \\ & {\left[6^{-14} \mathrm{C}\right] \text { Fructose }} & 1.11 & 0.09 & 4\end{array}$

\footnotetext{
* These values represent the specific activity of purified alginate, relative to that of the growth substrate. The relative specific activities are calculated as molar ratios. These calculations assume a value of 176 for the effective $M_{\mathrm{r}}$ of the uronic acid repeating unit in the polymer.
}

in the culture medium to inactivate the alginate lyase, as described by Hacking et al. (1983), allowed an improved recovery of alginate.

The purification of alginate from the radiolabelled cultures involved repeated precipitation of the polymer, followed by dialysis. This procedure was carried out to remove labelled material entrapped in the alginate gel during precipitation.

The incorporation of specifically labelled glucose into alginate by $A$. vinelandii and $P$. mendocina is summarized in Table 1 . The results show that, whereas only a small proportion of C-1 or C-2 of glucose was incorporated into alginate by either organism, the specific activity of alginate synthesized from $\left[6^{-14} \mathrm{C}\right]$ glucose was substantially higher than that of the substrate, in both cases. These results are in good agreement with those of Lynn \& Sokatch (1984) for the incorporation of labelled glucose into alginate by $A$. vinelandii and $P$. aeruginosa and confirm that the principal pathway of alginate biosynthesis involves cleavage of the glucose molecule, presumably via the Entner-Doudoroff pathway, as proposed by Banerjee et al. $(1983,1985)$. The small, but significant, amount of radioisotope recovered in alginate from bacteria grown on 1- or 2-labelled glucose probably represents synthesis of polymer from intact hexose units. 
Table 2. Comparison of the activities of the enzymes involved in the utilization of fructose by $P$. mendocina and $A$. vinelandii

The values presented are means of the activities of the enzymes in two cell-free extracts prepared from bacteria grown in batch culture with fructose as sole carbon source.

\begin{tabular}{lcc} 
& Specific activity [nmol $\mathrm{min}^{-1}\left(\mathrm{mg} \mathrm{protein}^{-1}\right]$ \\
\cline { 2 - 3 } \multicolumn{1}{c}{ Enzyme } & 220 & P. melandii \\
Fructokinase & ND & ND \\
1-Phosphofructokinase & 20 & 230 \\
Fructose-1,6-bisphosphatase & 22
\end{tabular}

ND, Not detected.

In contrast to the results obtained with specifically labelled glucose, there was substantial incorporation of both 1- and 6-labelled fructose into alginate by both organisms (Table 1). The greater incorporation of 6-labelled glucose again suggests the operation of parallel pathways, but in the case of fructose, the synthesis of polymer via the Entner-Doudoroff pathway is of minor importance, compared with direct synthesis from undegraded hexose units.

\section{Pathways of fructose and glucose metabolism}

Although similar results were obtained for the incorporation of specifically labelled glucose and fructose into both $A$. vinelandii and $P$. mendocina, the mode of fructose uptake differed in these organisms. A. vinelandii was found to have an ATP-dependent fructokinase or hexokinase (Table 2), whereas $P$. mendocina possessed a 1-phosphof ructokinase, in common with other pseudomonads, in which fructose is utilized via a fructose phosphotransferase system (Lessie \& Phibbs, 1984). Fructose-1,6-bisphosphatase activity was detected in cell-free extracts of both organisms (Table 2).

In an attempt to provide an explanation for the preferred indirect route of alginate synthesis from glucose, we investigated the metabolism of this substrate in $P$. mendocina. The organism was grown in continuous culture, under nitrogen limitation, whereby the yield of alginate is substantially greater than the biomass concentration (Hacking et al., 1983). The specific activities, in crude extracts, of various enzymes involved in the metabolism of glucose are given in Table 3.

Glucose 6-phosphate can be converted directly to F6P, the apparent precursor of alginate synthesis, by the action of PGI, or may be channelled through the Entner-Doudoroff pathway by the action of G6PD. The activity of PGI was substantially less than that of G6PD (Table 3). G6PD was found to be a regulatory enzyme, active with both NAD and NADP, for which ATP is a negative allosteric effector (Fig. 2). Although PGI could readily be assayed in the 'reverse' direction in a coupled assay using F6P as substrate, no satisfactory assay could be developed for the enzyme in the 'forward' direction, to allow the $K_{\mathrm{m}}$ value for G6P to be evaluated, but a value of $0.29 \mathrm{mM}$ was determined with F6P as substrate. 6PG is a competitive inhibitor of PGI with F6P as substrate, and a $K_{\mathrm{i}}$ value of $1.2 \mathrm{mM}$ was calculated for this inhibitor. The inclusion of $\mathrm{NaF}(50 \mathrm{~mm})$ to inhibit $6 \mathrm{PG}$ dehydratase blocked this reaction at the maximum concentration $(5 \mathrm{mM})$ of $6 \mathrm{PG}$ employed in the inhibition studies, indicating that the true inhibitor was 6PG, rather than some metabolite produced from this compound. Competitive inhibition of PGI by 6PG has previously been found with enzyme derived from peas (Hizukuri et al., 1975), cardiac tissue (Gracy \& Tilley, 1975) and Bacillus stearothermophilus (Nosoh, 1975); $K_{\mathrm{i}}$ values for 6PG of $13 \mu \mathrm{M}$ and $63 \mu \mathrm{M}$ have been reported for the pea and cardiac enzymes, respectively, in assays with $\mathrm{G} 6 \mathrm{P}$ as substrate.

It is likely that during growth of $P$. mendocina in medium containing glucose, the intracellular concentration of $6 \mathrm{PG}$ is sufficient to restrict the isomerization of G6P, so that the principal route of alginate synthesis is via the dehydrogenase rather than via the isomerase. Competitive inhibition of PGI by 6PG was also demonstrated in $A$. vinelandii (results not shown). 


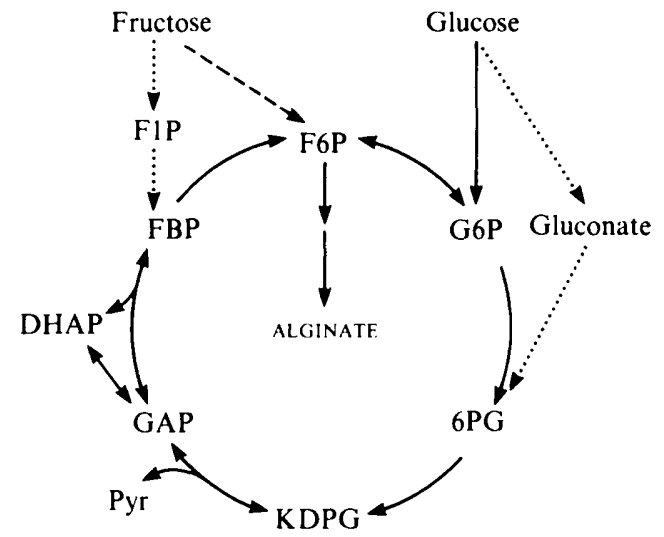

Fig. 3. Alternative pathways leading to alginate biosynthesis. $\longrightarrow P$. mendocina and $A$. vinelandii; , ....., $P$. mendocina; $\rightarrow A$. vinelandii. Abbreviations: F1P, fructose $1-$ phosphate; F6P, fructose 6phosphate; FBP, fructose 1,6-bisphosphate; G6P, glucose 6-phosphate; 6PG, 6-phosphogluconate; KDPG, 2-keto-3-deoxy-6-phosphogluconate; Pyr, pyruvate; GAP, glyceraldehyde 3-phosphate; DHAP, dihydroxyacetone phosphate.

Table 3. Activities of various enzymes of glucose catabolism in P. mendocina

The values presented are from three alginate-producing continuous cultures (nitrogen-limited) and show the range of activities present in cell-free extracts.

\section{Enzyme}

Glucokinase

Glucose dehydrogenase

Gluconate dehydrogenase

Gluconate kinase

Glucose-6-phosphate dehydrogenase

Glucose-6-phosphate isomerase

Entner-Doudoroff enzymes*

2-Oxogluconate enzymes†

Fructose-1,6-bisphosphate aldolase

Fructose-1,6-bisphosphatase

6-Phosphofructokinase
Specific activity [nmol $\mathrm{min}^{-1}$ (mg protein) ${ }^{-1}$ ]

$$
\begin{gathered}
83-164 \\
127-159 \\
\text { ND } \\
5-8 \\
274-456 \\
43-68 \\
18-26 \\
\text { ND } \\
27-39 \\
20-30 \\
\text { ND }
\end{gathered}
$$

ND, Not detected.

* Combined assay of 6-phosphogluconate dehydratase (EC 4.2.1.12) and 2-keto-3-deoxy-6-phosphogluconate aldolase (EC 4,1,2.14).

† Combined assay of dehydroglucokinase (EC 2.7.1.13) and phosphogluconate dehydrogenase (EC 1.1.1.43).

The oxidation of glucose to 2-ketogluconate, via gluconate, by membrane-bound dehydrogenases prior to transport across the cytoplasmic membrane is an important route of glucose metabolism in P. aeruginosa (Midgley \& Dawes, 1973; Roberts et al., 1973). Although glucose dehydrogenase was present in $P$. mendocina, neither gluconate dehydrogenase nor 2oxogluconate kinase/reductase activities were detected. In addition, washed cell suspensions of $P$. mendocina failed to produce 2-ketogluconate and this compound was not a substrate for the growth of the organism; $P$. aeruginosa was used as a positive control for these experiments (results not shown). Gluconate was detected in the culture medium when $P$. mendocina was grown under nitrogen limitation in glucose medium, but only at dilution rates lower than $0.05 \mathrm{~h}^{-1}$ (Sengha, 1985).

Pseudomonas strains normally lack 6-phosphofructokinase and are unable to degrade sugars via the Embden-Meyerhof pathway. Banerjee (1986) has recently provided evidence for the existence of this enzyme in mutant strains of mucoid $P$. aeruginosa but the significance of this 
finding, in relation to alginate biosynthesis, has yet to be demonstrated. 6-Phosphofructokinase was not detected in $P$. mendocina.

The apparent pathways available for glucose and fructose metabolism in $P$. mendocina and $A$. vinelandii are summarized in Fig. 3.

The biosynthesis of alginate from triose phosphates is less efficient than direct synthesis from hexose monomers since the dephosphorylation of FBP effectively wastes ATP; this suggests that, at least in $A$. vinelandii, fructose might be a better substrate than glucose for efficient conversion to alginate. This was found to be the case for batch cultures of $A$. vinelandii. Comparisons were made of the yield of alginate and biomass in batch culture of $A$. vinelandii grown under identical conditions, with glucose or fructose $\left(15 \mathrm{~g} \mathrm{l}^{-1}\right)$ as the carbon source. In six experiments with each substrate, glucose yielded [ $\mathrm{g}$ (mol substrate) $\left.{ }^{-1}\right] 37.8 \pm 3.2$ alginate and $20.8 \pm 3.2$ biomass, while fructose yielded $45.2 \pm 4.6$ alginate and $15.0 \pm 2.7$ biomass. Comparison of the alginate yields was not attempted for $P$. mendocina because the polymer is degraded, to some extent during growth, by an alginate lyase and quantitative recovery is difficult. In this organism, utilization of both substrates by their preferred routes involves the dephosphorylation of FBP.

Since alginate synthesized from glucose via the degradative route contains only three of the six carbon atoms present in the substrate, the conversion efficiency is limited to approximately $50 \%$. This conversion efficiency has been realized for $P$. mendocina U1 under optimum growth conditions in continuous culture (Sengha, 1985).

We are grateful to Mrs Anne Robertson for skilled technical assistance. Neutrase and Sweetzyme Q were gifts from Novo Enzyme Products Ltd, Windsor, Berkshire.

\section{REFERENCES}

ANDERSON, A. J. \& DAwES, E. A. (1985). Regulation of glucose 6-phosphate dehydrogenase in Zymomonas mobilis CP4. FEMS Microbiology Letters 27, 23-27.

BANERJEe, P. C. (1986). Accumulation of fructose 1,6bisphosphate in mutant cells of mucoid Pseudomonas aeruginosa as an evidence of phosphof ructokinase activity. Archives of Microbiology 144, 405-407.

Banerjee, P. C., Vanags, R. I., Chakrabarty, A. M. \& MaITRA, P. K. (1983). Alginic acid synthesis in Pseudomonas mendocina. Journal of Bacteriology 155 , 238-245.

Banerjee, P. C., Vanags, R. I., Chakrabarty, A. M. \& MAITRA, P. K. (1985). Fructose 1,6-bisphosphate aldolase activity is essential for synthesis of alginate from glucose by Pseudomonas aeruginosa. Journal of Bacteriology 161, 458-460.

Blumenkrantz, N. \& Absoe-Hansen, G. (1973). A new method for quantitative determination of uronic acids. Analytical Biochemistry 54, 484-489.

BRAY, G. A. (1960). A simple efficient liquid scintillator for counting aqueous solutions in a liquid scintillation counter. Analytical Biochemistry 1, 279285.

Darzins, A., Nixon, L. L., Vanags, R. I. \& Chakrabarty, A. M. (1985). Cloning of Escherichia coli and Pseudomonas aeruginosa phosphomannose isomerase genes and their expression in alginatenegative mutants of Pseudomonas aeruginosa. Journal of Bacteriology 161, 249-257.

van Dijken, J. P. \& Quayle, J. R. (1977). Fructose metabolism in four Pseudomonas species. Archives of Microbiology 114, 281-286.

DOELLE, H. W. (1982). The existence of two separate constitutive enzymes for glucose and fructose metabolism in Zymomonas mobilis. European Journal of
Applied Microbiology and Biotechnology 15, 20-24.

Gill, J. F., Deretic, V. J. \& Chakrabarty, A. M. (1986). Overproduction and assay of Pseudomonas aeruginosa phosphomannose isomerase. Journal of Bacteriology 167, 611-615.

Gracy, R. W. \& Tilley, B. E. (1975). Phosphoglucose isomerase of human erythrocytes and cardiac tissue. Methods in Enzymology 41, 392-400.

Hacking, A. J., TaYloR, I. W. F., JaRman, T. R. \& Govan, J. R. W. (1983). Alginate biosynthesis by Pseudomonas mendocina. Journal of General Microbiology 129, 3473-3480.

Herbert, D., Phipps, P. J. \& Strange, R. E. (1971). Chemical analysis of microbial cells. Methods in Microbiology 5B, 209-344.

Hizukuri, S., Takeda, Y. \& Nikuni, Z. (1975). Glucose 6-phosphate isomerase from peas. Methods in Enzymology 41, 388-392.

Horan, N. J., Jarman, T. R. \& Dawes, E. A. (1983). Studies on some enzymes of alginic acid biosynthesis in Azotobacter vinelandii grown in continuous culture. Journal of General Microbiology 129, 2985-2990.

JAYASURIA, C. G. N. (1955). The isolation and characteristics of an oxalate-decomposing organism. Journal of General Microbiology 12, 419-428.

KALB, V. F. \& BernlohR, R. W. (1977). A new spectrophotometric assay for protein in cell extracts. Analytical Biochemistry 82, 362-371.

Kovachevich, R. \& WOOD, W. A. (1955). Carbohydrate metabolism by Pseudomonas fluorescens. III. Purification of a 6-phosphogluconate dehydratase. Journal of Biological Chemistry 213, 745-756.

Lessie, T. G. \& PhibBs, P. V., JR (1984). Alternative pathways of carbohydrate utilisation in Pseudomonas. Annual Review of Microbiology 38, 359-387. 
LYNN, A. R. \& SOKATCH, J. R. (1984). Incorporation of isotope from specifically labelled glucose into alginates of Pseudomonas aeruginosa and Azotobacter vinelandii. Journal of Bacteriology 158, 1161-1162.

MiDGLey, M. \& DAWES, E. A. (1973). The regulation of transport of glucose and methyl $\alpha$-glucoside in Pseudomonas aeruginosa. Biochemical Journal 132, 141-154.

Mitchell, C. G. \& Dawes, E. A. (1982). The role of oxygen in the regulation of glucose metabolism, transport and the tricarboxylic acid cycle in Pseudomonas aeruginosa. Journal of General Microbiology 128, 49-59.

NosoH, Y. (1975). Glucose 6-phosphate isomerase from Bacillus stearothermophilus. Methods in Enzymology 41, 383-387.

Piggott, N. H., Sutherland, I. W. \& Jarman, T. R. (1981). Enzymes involved in the biosynthesis of alginate by Pseudomonas aeruginosa. European Journal of Applied Microbiology and Biotechnology 13, 179-183.
Pindar, D. F. \& BUCKe, C. (1975). The biosynthesis of alginic acid by Azotobacter vinelandii. Biochemical Journal 152, 617-622.

Pugashetti, B. K., Vadas, L., Prihar, H. S. \& FEINGOLD, D. S. (1983). GDP-mannose dehydrogenase and biosynthesis of alginate-like polysaccharide in a mucoid strain of Pseudomonas aeruginosa. Journal of Bacteriology 153, 1107-1110.

RoberTS, B. K., MidGLeY, M. \& DAWES, E. A. (1973). The metabolism of 2-oxogluconate by Pseudomonas aeruginosa. Journal of General Microbiology 78, 319329.

Sawyer, M. H., Baumann, P., Berman, S. J. Canovas, J. L. \& Berman, R. H. (1977). Pathways of D-fructose catabolism in species of Pseudomonas. Archives of Microbiology 112, 49-55.

SENGHA, S. S. (1985). The physiology and energetics of alginic acid biosynthesis in Pseudomonas mendocina. PhD thesis, University of Hull. 